\title{
Vanadate Induction of L-Type Pyruvate Kinase mRNA in Adult Rat Hepatocytes in Primary Culture
}

\author{
MONTSERRAT MIRALPEIX, JEAN-FRANÇOIS DECAUX, AXEL KAHN, AND RAMON BARTRONS
}

\begin{abstract}
In primary culture of adult rat hepatocytes, vanadate in the presence of glucose stimulates the expression of the liver (L-type) pyruvate kinase gene. Glucose by itself was inactive, and vanadate, like insulin, was also inefficient in the absence of glucose. Similar results were obtained on glucokinase gene expression. An analogue of CAMP, 8-(4-chlorophenylthio)-cAMP, inhibited the production of L-type pyruvate kinase and glucokinase mRNAs in the presence of glucose plus vanadate. Diabetes 40:462-64, 1991
\end{abstract}

$\mathbf{V}$ anadate has been reported to be a potent insulin mimetic agent in many cells (1-7). Oral administration of this compound to diabetic animals normalizes blood glucose concentration (8) and restores liver glycogen and fructose-2,6-bisphosphate levels and glucokinase and 6-phosphofructo-2-kinase activities (9). As a result of vanadate action, a switch from gluconeogenesis to glycolysis is produced in the diabetic rat liver.

The activity of liver (L-type) pyruvate kinase and its mRNA concentration fluctuate markedly according to the nutritional and hormonal status of the animal. Diabetes (10-12) and fasting $(13,14)$ cause a strong decrease in activity and mRNA levels. Insulin administration to diabetic rats $(10-12)$ or refeeding fasted rats with a high-carbohydrate diet $(13,14)$ produces an increase in both parameters. Insulin, glucocorticoids, and thyroid hormones appear to play a "permissive" role in the induction of L-type pyruvate kinase mRNA synthesis in response to carbohydrate feeding $(14,15)$. It has been shown that glucagon and its second messenger,

From the Division of Biochemistry, Department of Human Physiological Sciences and Nutrition, University of Barcelona, Barcelona, Spain; and the Laboratory of Genetic and Molecular Pathology Research, Paris, France.

Address correspondence and reprint requests to Dr. Ramon Bartrons, Division of Biochemistry, Department of Human Physiological Sciences and Nutrition, Universitat de Barcelona, Zona Universitaria de Bellvitge, 08907 L'Hospitalet, Barcelona, Spain.

Received for publication 5 July 1990 and accepted in revised form 1 November 1990
cAMP, block transcription of the gene for L-type pyruvate kinase $(12,14,15)$.

Decaux et al. (16) developed a model of adult rat hepatocytes in primary culture to study the action of different effectors on the expression of the L-type pyruvate kinase gene. In these cells, this gene is expressed only when glucose and insulin are present together, each of them being inactive by itself (16). Using the same model, we investigated the effect of vanadate on L-type pyruvate kinase gene expression.

\section{RESEARCH DESIGN AND METHODS}

All reagents were of the best grade available commercially. Sodium orthovanadate $\left(\mathrm{Na}_{3} \mathrm{VO}_{4}\right)$ was from Fisher (Silver Spring, MD).

Hepatocytes were isolated from 72-h-starved male Wistar rats (wt 200-250 g) as described previously (16). After removing nonparenchymal cells and debris, hepatocytes were suspended in medium 199 containing $5.5 \mathrm{mM}$ glucose, 1 $\mathrm{nM}$ insulin, $1 \mu \mathrm{M}$ thyroid hormones, and 10\% fetal calf serum, and $9 \times 10^{6}$ cells were plated in $5 \mathrm{ml}$ of medium 199 . Cultures were maintained at $37^{\circ} \mathrm{C}$ under an atmosphere of air $/ \mathrm{CO}_{2}$ $(19: 1)$. After $4 \mathrm{~h}$, the medium was removed and replaced by $10 \mathrm{ml}$ of fresh medium 199 containing $1 \mu \mathrm{M}$ thyroid hormones, $1 \mu \mathrm{M}$ dexamethasone, $10 \mathrm{nM}$ insulin, $10 \mathrm{mM}$ glucose, and no fetal calf serum, for 5 days. Then, the cells were cultured for $24 \mathrm{~h}$ in the presence of $10 \mathrm{mM}$ lactate alone, without glucose or insulin. Culture was extended after removing the medium containing lactate and by addition of vanadate with or without glucose, insulin with glucose, or glucose alone for $24 \mathrm{~h}$. The effect of an analogue of CAMP, 8-(4-chlorophenylthio)-cAMP (CPT-cAMP), was tested in the presence of vanadate plus glucose or insulin plus glucose also for $24 \mathrm{~h}$. The medium was changed every $24 \mathrm{~h}$. All experiments were performed in the presence of glucocorticoids and thyroid hormones as permissive hormones $(14,15)$. After these different treatments, cells were washed in isotonic saline solution, scraped out, and frozen at $-80^{\circ} \mathrm{C}$.

The extraction procedure of total RNA and Northern-blot analysis were performed (16). Filters were hybridized with 
L-type pyruvate kinase and glucokinase cDNA probes (16). The L-type pyruvate kinase cDNA probe corresponded to a 388-base pair (bp) Taq I-Pst I restriction fragment of the $11 \mathrm{C} 6$ clone, which was subcloned into the single-stranded phage $\mathrm{M} 13$ (17). The recombinant phage was used as a template for the synthesis of the complementary strand in the presence of the four deoxynucleotides, including a limited amount of $\left[\alpha{ }^{32} \mathrm{P}\right] \mathrm{dCTP}$. The glucokinase cDNA probe provided by lynedjian (18), was 1800 bp long and was labeled by random priming

\section{RESULTS}

To study the effects of vanadate on the expression of the $L$ type pyruvate kinase gene, we used the same experimental procedure as described by Decaux et al. (16). After 5 days of culture in the presence of $10 \mathrm{mM}$ glucose and $10 \mathrm{nM}$ insulin, the cells were cultured for $24 \mathrm{~h}$ in a medium containing $10 \mathrm{mM}$ lactate but not glucose or insulin. Hepatocytes were then cultured for $24 \mathrm{~h}$ in the presence of vanadate with or without glucose or with glucose plus insulin.

When hepatocytes were cultured for $24 \mathrm{~h}$ with vanadate plus lactate in the absence of glucose, after deprivation of glucose and insulin, no accumulation of L-type pyruvate kinase mRNA was observed (Fig. 1). Glucose alone was in-
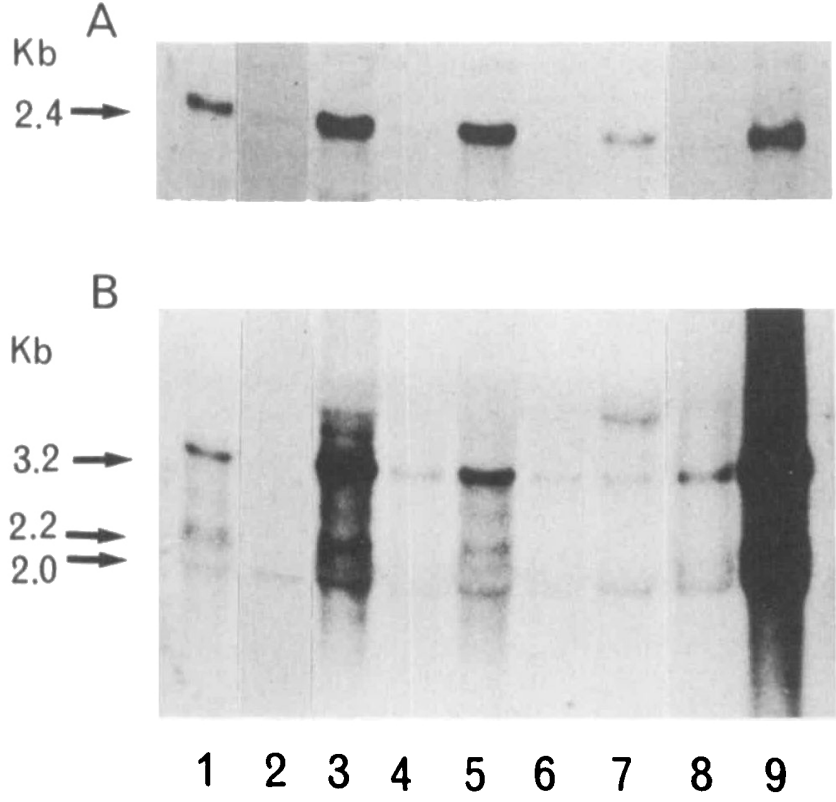

FIG. 1. Northern-blot analysis of total cellular RNAs after different culture conditions. Total cellular RNAs were isolated from pooled hepatocytes of 6-10 dishes for each culture condition. RNAs were denatured with methylmercury hydroxide and electrophoresed in $1.5 \%$ agarose gel (load of total cellular RNA was $30 \mu \mathrm{g} / \mathrm{lane}$ ). RNAs were then transferred to nylon filter and hybridized with ${ }^{32} \mathrm{P}$-labeled liver ( $L$ type) pyruvate kinase $(B)$ or with [32P]glucokinase $(A)$ CDNA probes. Similar results were obtained in 2 other experiments. Lane 1, $24 \mathrm{~h}$ of culture in presence of $10 \mathrm{mM}$ lactate alone, without glucose and insulin; lane 2, same as lane 1, then $24 \mathrm{~h}$ of culture in presence of 10 $\mathrm{mM}$ glucose; lane 3, same as lane 1 , then $24 \mathrm{~h}$ of culture in presence of $10 \mathrm{mM}$ glucose and $10 \mathrm{nM}$ insulin; lane 4 , same as lane 1 , then 24 $h$ of culture in presence of $10 \mathrm{mM}$ glucose, $10 \mathrm{nM}$ insulin, and $50 \mu \mathrm{M}$ CAMP analogue 8-(4-chlorophenylthio)-CAMP (CPT-CAMP); lane 5 , same as lane 1 , then $24 \mathrm{~h}$ of culture in presence of $10 \mathrm{mM}$ glucose and $25 \mu \mathrm{M}$ vanadate; lane 6 , same as lane 1 , then $24 \mathrm{~h}$ of culture in presence of $10 \mathrm{mM}$ glucose, $25 \mu \mathrm{M}$ vanadate, and $50 \mu \mathrm{M}$ CPT-CAMP; lane 7 , same as lane 1 , then $24 \mathrm{~h}$ of culture in presence of $10 \mathrm{mM}$ lactate and $25 \mu \mathrm{M}$ vanadate; lane 8 , liver from fasted rat; and lane 9, liver from carbohydrate-refed rat. Kb, kilobase. efficient in stimulating the expression of the L-type pyruvate kinase gene, as previously demonstrated (16). L-type pyruvate kinase gene was only expressed when glucose and vanadate were present together, as occurred with insulin plus glucose (16; Fig. 1). However, the increase of L-type pyruvate kinase mRNA levels in the presence of vanadate plus glucose was much less than that observed with insulin plus glucose. The accumulation of L-type pyruvate kinase mRNA in the presence of insulin plus glucose represented in vitro $<10 \%$ of that reached in vivo (16; Fig. 1 ); this figure decreased to $2 \%$ when insulin was replaced by vanadate.

The reaccumulation of L-type pyruvate kinase mRNA in the presence of glucose plus vanadate or glucose plus insulin was totally blocked by the addition of $50 \mu \mathrm{M}$ CPT-cAMP (Fig. 1). This transcriptional inhibitory effect of CAMP was not counteracted by glucose plus vanadate or glucose plus insulin (16; Fig. 1), as has been shown in refed animals (14).

To confirm these results, the Northern blots were also hybridized with a cDNA probe specific to hepatic glucokinase mRNA (18), because it has been previously demonstrated that vanadate treatment of diabetic rats, like insulin administration (19-21), restored the decreased hepatic glucokinase activity, probably by inducing the synthesis of the enzyme (9). This hypothesis is supported by the fact that there is a good correlation between mRNA levels, rate of synthesis, and activity of glucokinase enzyme in the experimental conditions in vivo (19-21) and in vitro (22-24). Hepatocytes cultured for $24 \mathrm{~h}$ in the presence of insulin plus glucose or vanadate plus glucose showed an increase in glucokinase mRNA levels compared with those after $24 \mathrm{~h}$ of culture in a "lactate" medium (Fig. 1). Addition of CPT-cAMP inhibited the production of the specific mRNA in both experimental conditions. These results are in line with those of lynedjian et al. (24).

\section{DISCUSSION}

Our results show that vanadate, in addition to the previously reported insulin mimetic effects (1-9), can also reproduce the hormone action on the expression of L-type pyruvate kinase gene. Like insulin, in the absence of glucose, vanadate is inefficient in stimulating the expression of the L-type pyruvate kinase gene. This result indicates that neither vanadate nor insulin has a direct role on transcription of the Ltype pyruvate kinase gene by itself, because glucose is required for its mechanism of action. The observation that the insulin receptor has tyrosine-specific protein kinase activity after insulin binding (25) and the fact that vanadate is a potent and selective inhibitor of phosphotyrosyl-protein phosphatases (26) suggest that both agents could alter the phosphorylation state of relevant substrates involved in insulin action. Studies in vivo clearly show that insulin action on the transcription of the L-type pyruvate kinase gene may not be direct, because protein inhibitors impair the induction of the gene caused by this hormone (12). In addition, fructose could stimulate transcription of the L-type pyruvate kinase gene in vivo in the absence of insulin probably by stimulating accumulation of a glycolytic intermediate $(10,12,27)$. As Decaux et al. (16) have hypothesized for the insulin-glucose-dependent stimulation of the gene, these results allow us to postulate that the vanadate-glucose-dependent increase of L-type pyruvate kinase levels also could 
depend on the presence of a transcriptional activator derived from carbohydrate metabolism and accumulated in the presence of vanadate plus glucose.

In conclusion, our results show that vanadate acts similarly to insulin on gene expression. In addition, the use of hepatocyte cultures allows us to exclude an indirect mechanism of vanadate in vivo, mediated by an increase in insulin secretion.

\section{ACKNOWLEDGMENTS}

This project was supported by Dirección General de Investigación Científica y Técnica (PM89-0049; Spain). J.F.D. was supported by a fellowship from the Foundation pour la Recherche Médicale Française.

We are much indebted to Dr. P. lynedjian for providing the glucokinase cDNA probe.

\section{REFERENCES}

1. Shechter $Y$, Karlish SJD: Insulin-like stimulation of glucose oxidation in rat adipocytes by vanadyl (IV) ions. Nature (Lond) 284:556-58, 1980

2. Dubyak GR, Kleinzeller A: The insulin-mimetic effects of vanadate in isolated rat adipocytes. J Biol Chem 255:5306-12, 1980

3. Tamura S, Brown TA, Whipple JH, Fujita-Yamaguchi Y, Dubler RE, Cheng $\mathrm{K}$, Larner J: A novel mechanism for the insulin-like effect of vanadate on glycogen synthase in rat adipocytes. J Biol Chem 259:6650-58, 1984

4. Green $A$ : The insulin-like effect of sodium vanadate on adipocyte glucose transport is mediated at a post-insulin-receptor level. Biochem J 238 663-69, 1986

5. Clark AS, Fagan JM, Mitch WE: Selectivity of the insulin-like actions of vanadate on glucose and protein metabolism in skeletal muscle. Biochem J 232:273-76, 1985

6. Tolman EL, Barris E, Burns M, Pansini A, Partridge R: Effects of vanadium on glucose metabolism in vitro. Life Sci 25:1159-64, 1979

7. Miralpeix M, Gil J, Rosa JL, Carreras J, Bartrons R: Vanadate counteracts glucagon effects in isolated rat hepatocytes. Life Sci 44:1491-97, 1989

8. Heyliger CE, Tahiliani AG, MCNeill JH: Effect of vanadate on elevated blood glucose and depressed cardiac performance of diabetic rats. Sci ence 227:1474-77, 1985

9. Gil J, Miralpeix M, Carreras J, Bartrons R: Insulin-like effects of vanadate on glucokinase activity and fructose 2,6-bisphosphate levels in the liver of diabetic rats. J Biol Chem 263:1868-71, 1988

10. Noguchi $T$, Inoue $H$, Tanaka $T$ : Regulation of rat liver L-type pyruvate kinase mRNA by insulin and by fructose. Eur J Biochem 128:583-88, 1982

11. Noguchi $T$, Inoue $H$, Chen $H-L$, Matsubara $K$, Tanaka T: Molecular cloning of DNA complementary to rat L-type pyruvate kinase mRNA. J Biol Chem 258:15220-23, 1983

12. Noguchi $T$, Inoue $H$, Tanaka $T$ : Transcriptional and posttranscriptional regulation of L-type pyruvate kinase in diabetic rat liver by insulin and dietary fructose. J Biol Chem 260:14393-97, 1985

13. Weber A, Marie J, Cottreau D, Simon M-P, Besmond C, Dreyfus J-C, Kahn $A$ : Dietary control of aldolase $B$ and L-type pyruvate kinase mRNAs in rat. J Biol Chem 259:1798-802, 1984

14. Vaulont S, Munnich A, Decaux J.F, Kahn A: Transcriptional and posttranscriptional regulation of L-type pyruvate kinase gene expression in rat liver. J Biol Chem 261:7621-25, 1986

15. Munnich A, Marie J, Reach $G$, Vaulont $S$, Simon M-P, Kahn A: In vivo hormonal control of L-type pyruvate kinase gene expression. J Biol Chem 259:10228-31, 1984

16. Decaux J-F Antoine $B$, Kahn A: Regulation of the expression of the Ltype pyruvate kinase gene in adult rat hepatocytes in primary culture. $J$ Biol Chem 264:11584-90, 1989

17. Lone YC, Simon MP, Kahn A, Marie J: Complete nucleotide and deduced amino acid sequences of rat L-type pyruvate kinase. FEBS Lett 195:97100,1986

18. Iynedjian PB, Ucla C, Mach B: Molecular cloning of glucokinase cDNA. $J$ Biol Chem 262:6032-38, 1987

19. Spence $T$ : Levels of translatable mRNA coding for rat liver glucokinase. $J$ Biol Chem 258:9143-46, 1983

20. Sibrowski $W$, Seitz HJ: Rapid action of insulin and cyclic AMP in the regulation of functional messenger RNA coding for glucokinase in rat liver. J Biol Chem 259:343-46, 1984

21. Iynedjian $P B, G j i n o v c i A$, Renold $A E$ : Stimulation by insulin of glucokinase gene transcription in liver of diabetic rats. J Biol Chem 263:740-44, 1988

22. Katz NR, Nauck MA, Wilson PT: Induction of glucokinase by insulin under the permissive action of dexamethasone in primary rat hepatocyte cultures. Biochem Biophys Res Commun 88:23-29, 1979

23. Spence JT, Merrill MJ, Pitot HC: Role of insulin, glucose, and cyclic GMP in the regulation of glucokinase in cultured hepatocytes. $J$ Biol Chem 256:1598-603, 1981

24. Iynedjian PB, Jotterand D, Nouspikel T, Asfari M, Pilot P-R: Transcriptional induction of glucokinase gene by insulin in cultured liver cells and its repression by the glucagon-cAMP system. J Biol Chem 264:21824-29, 1989

25. Kahn CR, White MF: The insulin receptor and the molecular mechanism of insulin action. J Clin Invest 82:1151-56, 1988

26. Swarup G, Cohen S, Garbers DL: Inhibition of membrane phosphotyrosylprotein phosphatase activity by vanadate. Biochem Biophys Res Commun 107:1104-109, 1982

27. Munnich A, Lyonnet S, Chauvet D, Van Schaftingen E, Kahn A: Differential effects of glucose and fructose on liver L-type pyruvate kinase gene expression in vivo. $J$ Biol Chem 262:17065-71, 1987 